\title{
THE HAGUE CONVENTION ON THE LAW APPLICABLE TO SUCCESSION TO THE ESTATES OF DECEASED PERSONS: DO QUASI-COMMUNITY PROPERTY AND MANDATORY SURVIVORSHIP LAWS NEED PROTECTION?
}

\author{
CAROL S. BRUCH*
}

INTRODUCTION

The Hague Convention of 20 October 1988 on the Law Applicable to Succession to the Estates of Deceased Persons (Succession Convention) ${ }^{1}$ clarifies succession law for those who have important connections with more than one country. It provides choice-of-law rules for intestacy, and, for those who write wills, it specifies the testator's permissible choice of law.

This article does not evaluate the overall desirability of the Convention, a matter currently being debated elsewhere. Rather, it concerns one aspect of the Convention that affects cases in which a testator has specified a choice of law consistent with the Convention. It discusses mandatory survivorship rules, including quasi-community laws, and considers the possible effects of the testator's choice of law on them. It then evaluates an authorized reservation to the Convention that would modify those effects. The analysis concludes that if the United States ratifies the Convention, it should enter that reservation in order to preserve certain family protection policies. ${ }^{2}$

Copyright (C) 1993 by Carol S. Bruch

* Professor of Law, University of California, Davis.

The author expresses her warm appreciation to the Law Departments of the London School of Economics and Political Science and King's College (London), and the Institut fur Internationales RechtRechtsvergleichung of the University of Munich for their hospitality during the preparation of this work, and to the Alexander von Humboldt Foundation (Germany) for its financial support. She also expresses her sincere thanks to Professor William Reppy, Jr. and Duke Law School students Philip Combs and Matthew Watson for their invaluable assistance in documenting the footnotes.

1. 28 I.L.M. 146 (1989); HAGUE CONFERENCE ON PRIVATE INTERNATIONAL LAW, PROCEEDINGS OF THE SIXTEENTH SESSION, tome I, 24-33 (1988) [hereinafter Succession Convention]. See generally id. tome II: Succession to Estates-Applicable Law (1990) [hereinafter 2 SUCCESSION PROCEEDINGs]; Hans van Loon, The Hague Convention on the Law Applicable to Succession to the Estates of Deceased Persons, 1989 HAGUE YEARBOOK OF INT'L L. 48; Jeffrey A. Schoenblum, Choice of Law and Succession to Wealth: A Critical Analysis of the Ramifications of the Hague Convention on Succession to Decedents' Estates, 32 VA. J. INT'L L. 83 (1991); Eugene F. Scoles, Planning for the Multinational Estate, 3 PROBATE \& PROPERTY, May-June 1989, at 58.

2. The U.S. State Department is currently considering whether to recommend ratification of the Convention. In connection with that review, the matters discussed in this article are being considered by members of the Secretary of State's Advisory Committee on Private International Law (one of several 


\section{MANDATORY FAMILY PROTECTION}

Provisions for surviving family members have long been a subject of mandatory rules. In many civil law countries, specific shares of an estate (forced shares) are guaranteed to certain survivors. ${ }^{3}$ In most common law countries, there are no forced share provisions, but a court is authorized to review a testator's disposition and to make various capital or support deviations from it (family provision) for the protection of certain survivors. ${ }^{4}$

American law, compared to the law of many other countries, has been relatively circumscribed in providing either kind of protection. Unlike civil law countries, which provide forced shares to children, almost all of the states in this country confine forced shares to surviving spouses. ${ }^{5}$ And in contrast to other

groups whose views are solicited) and other interested academics. See Letter from Professor Carol Bruch to Harold Burman, Esq., Office of the Legal Adviser/PIL, Department of State with attached Draft Memorandum (Mar. 3, 1991); Letter from Professor Peter Hay to Professor Bruch (Mar. 11, 1991); Letter from Professor Eugene Scoles to Professor Bruch (Mar. 11, 1991) [hereinafter Scoles-Bruch Letter (Mar. 11, 1991)]; Letter from Professor Arthur von Mehren to Professors Carol Bruch, Edward Halbach, Peter Hay, Friedrich Juenger, and Eugene Scoles (Aug. 9, 1991); Letter from Professor Bruch to Professor Scoles (Sept. 22, 1991) [hereinafter Bruch-Scoles Letter (Sept. 22, 1991)]; Letter from Professor Bruch to Harold Burman with attached Memorandum (Sept. 23, 1991) [hereinafter Bruch-Burman Letter (Sept. 23, 1991) and Bruch Memorandum, respectively]; Letter from Professor Scoles to Professor Bruch with attached Memorandum (Oct. 29, 1991) [hereinafter Scoles-Bruch Letter (Oct. 29, 1991) and Scoles Memorandum, respectively]. (Copies of all letters and related memoranda on file with office of Law and Contemporary Problems.) Professor Scoles was a member of the United States delegation to the Hague meetings where the Convention was drafted. The views expressed in these documents and in this article are those of individuals and do not represent the views of the United States, which has not yet taken a position on the issues discussed. Note 40 infra reports on the status of similar discussions in England and Ireland. Professor Schoenblum takes the view that the Convention is not an appropriate vehicle for addressing the substantive issue of family protection, but his remarks favoring mandatory provisions of the law of final residence or nationality suggest that he might support Reservation $1 d$ if, contrary to his recommendations, the Convention is ratified with immediate effect in all states. See Schoenblum, supra note 1 , at $124-26$.

3. See, e.g., BGB $\$ \S 1371,1922,1924,1931,2303-2338$ a (F.R.G.).

4. See, e.g., Inheritance (Provision for Family and Dependants) Act 1975, $\$ \S 1-3$ (Eng.).

5. Statutes protecting spouses are found in most of this country's common law property states, but not in South Dakota. Eugene F. Scoles \& Edward C. Halbach, JR., Problems and Materials ON DECEDENTS' ESTATES AND TRUSTS 82 (3d ed. 1981). The nine community property states generally rely on marital property rules to distribute assets between spouses at death and do not provide a forced share in the decedent's separate or community assets except where the doctrine of quasi-community property applies. See id. at 82-83 (referring to eight states; Wisconsin has since become the ninth). A special allowance for spouses and children is, however, authorized by Wisconsin Statutes Annotated \& 861.35 (West 1991), and Louisiana has a forced share for needy spouses and some descendants.

Spousal forced heirship in Louisiana is called the marital portion. A spouse's entitlement to the marital portion is determined by weighing the survivor's wealth against the property in the decedent's "succession" (estate). LA. CIV. CODE ANN. art. 2432 (West 1985). The amount of the marital portion (which may not exceed $\$ 1$ million) and the extent to which it is limited to a life estate rather than outright ownership depends on the number of surviving children. Id. art. 2434 (West Supp. 1992). The share may not be renounced or altered by an agreement between the spouses. Id. art. 2330 (West 1985).

The Louisiana forced heirship for children is called the legitime. The broad forced heirship regime for children that Louisiana had from the time of settlement until 1990 has been cut back severely. Now only children under the age of 23 or with severe mental or physical handicaps receive forced shares. Id. art. 1493 (West Supp. 1992). Some scholars have criticized this scaling back of the legitime, arguing that it is contrary to the Louisiana Constitution, which provides that forced heirships may not be abolished. 
common law countries, American practice generally restricts discretionary protection to family allowance schemes that provide only short-term support while the estate is being settled. ${ }^{6}$

No forced share in the decedent's separate property or in the decedent's share of community assets exists in most community property states. ${ }^{7}$ The equivalent of a generous forced share is available to a surviving spouse in some states, however, through the doctrine of quasi-community property. ${ }^{8}$ This doctrine gives the survivor one half of assets in the estate that were acquired by the decedent's efforts during the marriage while domiciled in a non-community property jurisdiction. ${ }^{9}$

No marital property interest existed in these assets during the marriage. Rather, consistent with the marital property regime under which they were acquired, they were the separate property of the acquiring spouse. Nevertheless, the quasi-community property doctrine permits the nonowner spouse to receive a portion of such property at divorce ${ }^{10}$ or, in some states, upon the owner's death. ${ }^{11}$ At divorce, the assets are divided by analogy to the rules controlling

See, e.g., Katherine Shaw Spaht et al., The New Forced Heirship Legislation: A Regrettable "Revolution," 50 LA. L. REv. 409 (1990). See generally Paul G. Haskell, The Power of Disinheritance: Proposal for Reform, 52 GEORGETOWN L.J. 499, 518-25 (1964) (recommending, inter alia, protection for children and needy parents).

6. See Eugene F. SCOles \& Peter Hay, Conflict of Laws \$ 20.15, at 823 (2d ed. 1992); Unif. PROB. CODE § 2-404 (1990), 8 U.L.A. 107 (Supp. 1992) (authorizing "a reasonable allowance . . . for maintenance during the period of administration, [but not] for longer than one year if the estate is inadequate to discharge allowed claims"). Section 2-404 carries forward the language of $\S 2-403$ in earlier versions of the Uniform Probate Code. See 8 U.L.A. 98 (1983). But see WIS. STAT. ANN. \& 861.35 (West 1991) (authorizing long-term allowances).

7. An exception is Louisiana, a community property state that provides forced shares (the legitime) to children under the age of 23 and certain protections (usufruct and the marital portion) to a surviving spouse. See LA. CIV. CODE ANN. arts. 890, 1493, 1495, 2432, 2434 (West 1985 \& Supp. 1992); supra note 5. See also WIS. STAT. ANN. \$\$ 861.33-.41 (West 1991) (authorizing generous personal property exemptions and long-term support for qualifying surviving spouses and minor children).

8. See infra notes 10-16 and accompanying text.

9. More precisely stated, the quasi-community property doctrine reaches property acquired elsewhere that would have been considered community property if all events had occurred locally. Accordingly, in some circumstances it may also affect assets that were acquired not through personal efforts, but rather as passive earnings (such as rent or interest) on separate property. This may occur if the state in which the parties were domiciled at the time the earnings were acquired characterizes the "rents and profits" from separate property as separate property (either because it is a common law property state, or because it is a community property state with the doctrine that the "fruits" of property retain the same character as the "tree"). If a community property state which must later deal with the fruits considers, to the contrary, that earnings on separate property constitute community property, and if that state has an applicable quasi-community property law, it will treat these "separate property" earnings as quasi-community property. As a consequence, the spouse who did not own the underlying property will receive a share in the earnings attributable to it.

10. California, Arizona, Louisiana, Texas, and Wisconsin follow this rule. CAL. CIV. CoDE $\$ \S 4800$, 4803 (West 1983 \& Supp. 1992); ARIZ. REV. STAT. ANN. \& 25-318 (1991); LA. CIV. CODE ANN. art 3526 (West Supp. 1992); TEX. FAM. CODE ANN. $§ 3.63$ (West Supp. 1992); WisC. STAT. ANN. \$\$ 766.75, 767.255 (West 1981 \& Supp. 1991) (parties own as equal tenants in common unless the court has provided otherwise in the exercise of its power to make an equitable distribution of the property; an equal division is presumptively equitable).

11. California, Idaho, Louisiana, and Wisconsin follow this rule. See CAL. Prob. Code $\$ \$ 66,101$, 6101 (West 1991); IDAHO CODE § 15-2-201 (1979); LA. CIV. CODE ANN. art. 3526 (West Supp. 1992); WIS. STAT. ANN. $\& 861.02$ (West 1991). Although Texas law distinguishes quasi-community property 
community property, and there is little reason to note their distinctive character. $^{12}$ But their treatment in probate reveals quite clearly the degree to which the doctrine is predicated on separate property principles.

In contrast to the principles of community property ownership (where each asset acquired through either spouse's efforts belongs one half to the estate and one half to the survivor), quasi-community property rights at death operate in one direction only, favoring the survivor. That is, although the survivor receives one half of the decedent's quasi-community property acquisitions, no share of those assets acquired by the survivor's labor during marriage is in any way included in the decedent's estate. ${ }^{13}$ This lopsided treatment is consistent with the historical rationalization of the survivor's rights-they are the survivor's forced share in what was the decedent's separate property ${ }^{14}$ and not a product of shared ownership principles (which would require instead that one half of the survivor's quasi-community property acquisitions also be included in the decedent's estate). This analysis has been thought necessary to sustain the doctrine's constitutionality: although there may be due process concerns about taking property from the owner during his or her lifetime, ${ }^{15}$ they do not bar redistribution by property division at divorce or redistribution through a forced share in favor of a surviving family member upon the owner's death. ${ }^{16}$

If, consistent with this historical explanation, quasi-community property rights are deemed rights of survivorship for purposes of the Succession Convention,

from separate property for purposes of divorce, the courts have declined to extend this logic to the probate context absent a legislative command. Compare Cameron v. Cameron, 641 S.W.2d 210, 220-21 (Tex. 1982) with Estate of Hanau v. Hanau, 730 S.W.2d 663 (Tex. 1987). Scoles and Hay question this restriction and suggest that state courts should extend the doctrine of quasi-community property to the probate context through case law. SCOLES \& HAY, supra note $6, \S 14.14$, at 489 \& n.7.

12. In one particular, however, the relevant distinction is clear. Because the asset was separate property during the marriage, the nonowner spouse cannot complain about the fashion in which it was managed or dissipated. In other words, no management constraints impinge on the owner's full enjoyment of his or her quasi-community property. Although California now provides creditors with access to quasi-community property on the same basis as access to community property, this somewhat anomalous statutory development can be seen as no more than an application of apparent agency law. See CAL. Civ. CoDE $\$ 5120.120$ (West Supp. 1992).

13. See, e.g., CAL. Prob. CODE $\$ \$ 66,101,6101$ (West 1991) (providing equal ownership interests only in quasi-community property earned by the decedent, and including the decedent's share of that property in his or her estate; no division of the quasi-community property earned by the survivor is prescribed, and no portion of the quasi-community property earned by the survivor goes into the decedent's estate).

14. See SCOLES \& HALBACH, supra note 5, at 83. For a comment on the Texas law, see note 11 supra.

15. See Paley v. Bank of America, 324 P.2d 35 (Cal. Ct. App. 1958). The perceived constitutional constraints have been challenged elsewhere. See Carol S. Bruch, The Definition and Division of Marital Property in California: Towards Parity and Simplicity, 33 HASTINGS L.J. 769, 827 n.230 \& authorities cited (1982). But cf. Susan Mayer, Treating Quasi-Community Property as Community Property for Debt Collection: Due Process and Policy Concerns, 28 SANTA ClARA L. Rev. 905, 911-13 (1988); William A. Reppy, Jr., Retroactivity of the 1975 California Community Property Reforms, 48 S. CAL. L. REV. 977 , 1075-82 (1975). Mayer and Reppy do not challenge the constitutional doctrine, but they disagree with one another as to its implications.

16. See, e.g., Addison v. Addison, 399 P.2d 897 (Cal. 1965); SCOLES \& HAY, supra note 6, at 476-79; Friedrich K. Juenger, Marital Property and the Conflict of Laws: A Tale of Two Countries, 81 Colum. L. REV. 1061, 1074-75 (1981). 
they will be regulated by the Convention's rules on mandatory survivorship. ${ }^{17}$ Common law states' spousal forced share provisions, which generally reach one third of the decedent's estate,$^{18}$ are subject to the Convention in any event.

When, then, do quasi-community property laws and other forced share provisions apply under current American choice-of-law rules, and how would their reach be affected by the Convention?

\section{III}

\section{Current American Choice-of-Law Rules in Probate LaW}

In the United States, it is a black-letter conflicts rule that the law controlling rights in and succession to a decedent's personalty is that of the decedent's domicile at death. ${ }^{19}$ Although the traditional rule has been that the decedent's realty is subject instead to the law of its situs ${ }^{20}$ courts in which a decedent's land lies increasingly also apply the law of the decedent's final domicile. ${ }^{21}$ Their goal is to promote "unity of succession"-that is, disposition of the estate's assets, wherever they are located, according to one (hence consistent) law.

Accordingly, an American may choose the law that will control his or her estate (including mandatory survivorship provisions) only through an effective choice of domicile and careful attention to the location of realty that will come within his or her estate. ${ }^{22}$ In contrast, an attempt to choose the applicable law

17. As discussed below, to the extent that quasi-community property rules are deemed forced shares, the Convention permits them to be avoided by the testator's choice of law. Absent Reservation $1 d$, this may occur whenever the decedent has made an acceptable choice of law under Article 5. Even with Reservation $1 d$, they may be avoided whenever the decedent and the surviving spouse do not share the strong forum connections required by the reservation or (even when they do) if the resulting property loss is not serious enough to invoke the reservation. See infra note 34 and accompanying text.

Although Professor Scoles initially questioned whether quasi-community property laws would be treated as laws of succession or forced shares for purposes of the Convention, he now concludes that California's scheme probably would be. Compare Scoles-Bruch Letter (Mar. 11, 1991), supra note 2, at 4, with Scoles-Bruch Letter (Oct. 29, 1992), supra note 2, at 3. If, contrary to his view and that of this author, they are deemed marital property rights, they will fall outside the Convention, which expressly states that it "does not apply to . . . issues pertaining to matrimonial property." Succession Convention, supra note 1 , art. 1 , para. $2 c$. In that case, of course, the survivor's quasi-community property rights will be protected by matrimonial property law, and the decedent's choice of law will be irrelevant. But the problems identified in this article will nevertheless affect all other mandatory survivorship provisions, including those favoring spouses typically found in common law property states.

18. William M. MCGOVERn, JR., Sheldon F. KuRTZ \& JAN Ellen Rein, Wills, Trusts and ESTATES INCLUDING TAXATION AND FUTURE INTERESTS \$ 1.2, at 3-4 (1988). It should be noted that, in contrast to community property systems, common law forced shares apply to all of the decedent's assets, however acquired. If significant amounts of the decedent's assets were acquired prior to marriage, or through gift or inheritance, the forced share available in a common law state may provide a larger overall recovery by a spouse than would be received in a community property state.

19. SCOLES \& HAY, supra note $6, \S 20.15$, at 821 .

20. Id.; RESTATEMENT (SECOND) CONFLICT OF LAWS \& 242 (1971).

21. See SCOLES \& HAY, supra note 6, $\$ 20.15$, at 823 \& n.11; UNIF. PROB. CODE art. II, pt. 2, Elective Share of Surviving Spouse, General Comment (1990), 8 U.L.A. 73 (1983) ("Uniformity of law on the problems covered by this Part is much to be desired. It is especially important that states limit the applicability of rules protecting spouses so that only estates of domiciliary decedents are involved.").

22. See, e.g., Newcomb's Estate, 84 N.E. 950 (N.Y. 1908). 
by testamentary election will be unsuccessful to the extent that it does not comport with the mandatory features of the otherwise applicable law. ${ }^{23}$

Although the unity of succession doctrine cures inconsistencies when assets are left in more than one jurisdiction, it does not address the difficulties faced by those who plan their estates while domiciled in one state, only to move later to a sister state. And when similar cases involve not only sister states but also foreign countries with varying choice-of-law rules, courts are faced with even greater complications.

23. See Estate of Clark, 236 N.E.2d 152 (N.Y. 1968); RESTATEMENT (SECOND) CONFLICT OF LAwS $\$ \S 242$ (applying mandatory provisions of the situs to realty), 265 (applying mandatory provisions of last domicile to movables) (1971); UNIF. PROB. CODE § 2-602 (1990), 8 U.L.A. 129 (1983). But see Estate of Renard, 437 N.Y.S.2d 860 (N.Y. Surr. Ct.), affd, 447 N.Y.S.2d 573 (N.Y. App. Div. 1981), aff'd, 439 N.E.2d 341 (N.Y. 1982) (honoring statutorily authorized choice-of-law provision). Clark and Renard are discussed in SCOLES \& HAY, supra note 6, $\$ 20.15$, at 821-23. The decedent in Renard, a U.S. citizen who spent her retirement years in France after 30 years in New York, left assets in New York. Her adult child, who lived in California but held dual U.S.-French citizenship, sought to recover a forced share under French law, arguing that France was his mother's domicile at death. He was unsuccessful. (He would be equally unsuccessful under the Convention, whether or not the reservation that is the subject of this Article is entered.) Renard may well be confined to cases that involve a relevant statutory authorization. Cf. N.Y. EsTATES, Powers \& Trusts L. \& 3-5.1(h) (McKinney 1981); FLA. STAT. ANN. $\S 731.106$ (West 1976 \& Supp. 1993); ILL. ANN. STAT. ch. 110 1/2, para. 7-5 (Smith-Hurd 1978 \& Supp. 1992) (statutes applying local law to test the validity of choice-of-law clauses made by residents of foreign countries that direct the application of local law to their local assets); 1 WILLIAM H. NEWTON, III, INTERNATIONAL ESTATE PLANNING \$2.24 \& nn.3, 12-15 (1989); Robert A. Hendrickson, Choice-of-Law Directions for Disposing of Assets Situated Elsewhere than the Domicile of Their Owner-the Refractions of Renard, 18 REAL PROP. PROB. \& TR. J. 407, 414 (1983); Schoenblum, supra note 1, at 119 \& n.148, 124-25 (suggesting that New York and some other states seek foreign investments that are designed to avoid foreign forced share provisions). Professor Scoles' comments are not to the contrary, although their carefully crafted wording may suggest otherwise to a casual reader. See, e.g., Memorandum by Eugene F. Scoles, The 1988 Hague Convention on the Law Applicable to Decedents' Estates 5 (Dec. 12,1988 ) ("American courts and lawyers are familiar with testator control of the applicable law on many matters by using a choice of law clause in the will ....") (emphasis added). This memorandum and Professor Scoles' related publication, supra note 1, at 58, contain other remarks that do not, in fact, state that the common law embraces a testator's ability to designate the law that will apply to the mandatory survivorship provisions controlling his estate, but seem to imply this possibility. See, e.g., Lisa N. Frankel, Note, Ratification of the Hague Conference [sic] on the Law Applicable to the Estates of Deceased Persons: Toward Uniformity in United States Estate Planning, 12 N.Y. L. SCH. J. INT'L \& COMP. L. 177, 188-89 (1990), quoting Professor Scoles' statement that "civil law countries, where the concept is largely unknown, found ... 'testator autonomy' difficult to accept. At the same time, testamentary control was important to common law countries that recommended the estate planning necessity of being able to designate the governing law with some certainty." Neither of these quotations by Scoles actually asserts that U.S. courts recognize an attempt to designate the applicable law so far as mandatory provisions are concerned (in contrast, for example, to questions of execution or interpretation). Any such assertion would be inaccurate except as to the statutorily constructed rule of a few states (noted above) that encourages local investment by foreign domiciliaries who seek to avoid the constraints of their domestic probate laws. Consensual deviations from mandatory provisions are, in contrast, generally allowed so that in most circumstances a property owner is free to persuade those who are protected by the nonyielding provisions of a state's probate laws to waive their rights. Under U.S. law, such waivers, when validly entered into, are honored whether or not they are based on valuable consideration. See MCGOVERN et al., supra note 18, § 3.9 at 127-28; Paul G. Haskell, The Premarital Estate Contract and Social Policy, 57 N.C. L. REV. 415, 424, 428-29 (1979). For the Louisiana rule prohibiting such waivers, see note 5 supra. 


\section{The SuCCESSION CONVENTION'S Rules CONTROLling AN EXPRESS CHOICE OF LAW}

In order to ameliorate the ambiguities of current law for those whose circumstances may involve more than one country, the Succession Convention authorizes a testator to choose the law that will control succession to his or her estate:

A person may designate the law of a particular State to govern the succession to the whole of his estate. $\left[{ }^{24}\right]$ The designation will be effective only if at the time of the designation or of his death the person was a national of that State or had his habitual residence there. ${ }^{25}$

This rule integrates much European practice, which applies a nationalitybased choice-of-law rule, often to the entirety of a decedents' estate, ${ }^{26}$ and common law practice concerning movables in the estate, which looks to domicile. In doing so, it seeks to relieve both the problems posed when estates contain assets in several countries and those caused by international mobility (conflicts in time). It avoids the difficulties of ascertaining domicile (which requires evaluation of a person's subjective intent to make a place his or her home) $)^{27}$ by using instead the term "habitual residence," an objective standard. ${ }^{28}$

This attempt to relieve conflicts in time has certain disadvantages, however, when viewed from the standpoint of family protection. On one hand, a chosen law with no connection to the testator at the time the instrument is signed may nevertheless ultimately control. For such cases, the sole requirement is that a connection of either nationality or habitual residence thereafter be established that subsists on the date of death. This rule permits individuals to make estate plans in anticipation of a move-for example, for employment or retirement abroad. As a consequence, however, to the extent that various nations' immigration and visa policies welcome the testator, the rule also provides the testator with a generous opportunity for "choice-of-law shopping." As in the

24. Art. 5, para. 2 requires that the designation "be expressed in a statement made in accordance with the formal requirements for disposition of property upon death." Apparently this may be extraneous to the will. See Schoenblum, supra note 1, at 119 n.147; Donovan W.M. Waters, Explanatory Report (May 1989), 2 SUCCESSION PROCEEDINGS, supra note 1, art. 6, cl. 73, at 563. For purposes of simplicity, this article refers to designations as though they are effectuated at the time of executing the will.

25. Succession Convention art. 5, para. 1 (emphasis added).

26. See Georges A.L. Droz, Commentary on the Questionnaire on Succession in Private International Law, 2 SUCCESSION PROCEEDINGS, supra note 1, at 19, 21 -23 (citing Germany, Spain, Sweden, Greece, Czechoslovakia, the Netherlands, and Yugoslavia, as well as Japan and the United Arab Republic as countries that apply the nationality principle to the entire estate, and Turkey and, sometimes, Luxembourg and Austria as countries that apply this law to movables in the estate). In contrast, Brazil, Israel, Switzerland, Denmark, and Norway are listed as countries applying the law of the deceased's domicile to the entire estate, with France, Belgium, England, Scotland, Canada, the United States and, sometimes, Austria applying this law to movables in the estate. Id. at 23-25.

27. See, e.g., RESTATEMENT (SECOND) OF CONFLICT OF LAWS $\$ 18$; SCOLES \& HAY, supra note $6, \S 4.20$, at $185-86$.

28. SCOLES \& HAY, supra note $6, \S 4.14$, at 176-77. See generally Schoenblum, supra note 1, at 106 $07 \& \mathrm{nn}$. 94-95 (surveying discussions of the term). 
current American interstate context, one predictable yet questionable motive for such "shopping" may be to find a law that will permit the testator to leave far less to his or her close survivors than would be permitted by the law of the testator's current nationality or habitual residence. Indeed, the problem may be exacerbated, given the wider disparity among the laws of various nations.

On the other hand, for testators who choose the law of a place to which they are closely related at the time of execution (through either nationality or habitual residence), that choice will remain effective at death, even if the testator and close survivors then share nationality or habitual residence elsewhere. As a result, depending on the content of the respective states' laws, survivors may find themselves treated significantly less well under the law chosen at an earlier time than they would have been by the mandatory survivorship provisions of the only place with which they and the decedent were closely connected at the date of the testator's death.

As noted, these features of the Convention's rule were designed not to harm survivors, but rather to ameliorate the difficulties of "conflicts in time" for testators-it allows them to clarify an otherwise confusing legal situation that might otherwise be settled only after their death through painful and costly litigation. Yet each may also leave survivors who feel they have been victimized, however unintentionally, by the Convention's rules. Those placed at risk are close family members whose interests the testator seeks to defeat. Their vulnerability arises because the Convention provides that a permissibly chosen law will govern all succession rights, including those imposed by law for the protection of survivors. ${ }^{29}$

Recognizing this danger, the Australian delegation requested that countries be permitted to enter a reservation to the Convention that would place restrictions on the basic choice-of-law rule in a narrow set of cases. ${ }^{30}$ The proposal, which reflected great concern by many countries throughout the debates, ${ }^{31}$ was incorporated into the Convention in Article 24, paragraph $1 d$

29. Although most of the Convention's permitted choices seem unobjectionable at first reading, designation of a law with which the testator is connected by neither nationality nor habitual residence at the time is troublesome. Ironically, from a U.S. perspective, this is precisely what is permitted by current U.S. law, which allows a testator to choose the law by establishing domicile in the place with the desired law. In similar fashion, the Convention ratifies the would-be choice only upon the testator's acquisition of nationality or habitual residence in the state with the desired law. In any event, this choice (supported by an actual relocation) may be less objectionable than that which is honored when the law that has been chosen by the testator has little remaining relevance to the family by the time of his or her death. It is that latter fact pattern to which the reservation discussed in this article is addressed.

30. See Working Document No. 100, 2 SUCCESSION PROCEEDINGS, supra note 1, at 335-36. This proposal, which became Reservation $1 d$, was seen as providing a narrower exception than the United Kingdom proposal set forth by Working Document No. 95 and included in the Convention as Reservation $1 c$ of Article 24. See id. at 335, 492-94. The United States voted in opposition to the British draft but in favor of Reservation $1 d$. Id. at $492,494$.

31. Extensive portions of the minutes are devoted to expressions of concern by many countries that the Convention's deference to the testator's choice of law might improperly defeat family protection policies. See, e.g., id. at 319, 320, 324, 325, 335 (Working Document Nos. 60 (Australia), 64, 65 \& 92 (France \& Italy), 68 \& 100 (Australia), 73 (Denmark), 78, (Australia, Belgium, Canada, Chile, Israel, Mexico, \& Venezuela), 79 \& 95 (United Kingdom)), and related discussions. 
("Reservation 1d"). Reservation $1 d$ and a related provision not discussed here, Reservation $1 c{ }^{32}$ raise an important policy question concerning the familyprotective features of quasi-community property law and of succession law more generally.

It is important to place the matter in context. For countries that enter no reservation, the mandatory rules applicable to the estate will be those of the law chosen by the testator. But even in countries that do enter Reservation $1 d$, the testator's choice will control except for estates involving both decedents and survivors with heavy local connections. The relevant language reads:

1 Any State may . . . make [the following reservation]-

... .

$d$ that it will not recognize a designation made under Article 5 [defining a testator's permitted express choice of law], if all of the following conditions are met

-the law of the State making the reservation would have been the applicable law under Article 3 [which provides the choice of applicable law absent an effective express choice of law ${ }^{33}$ ],

-the application of the law designated under Article 5 would totally or very substantially deprive the spouse or a child of the deceased of an inheritance or family provision to which the spouse or child would have been entitled under the mandatory rules of the law of the State making this reservation,

-that spouse or child is habitually resident in or a national of the State making this reservation. ${ }^{34}$

32. Art. 24, para. $1 c$ reads:

Any State may ... make [the following reservation] -

....

$c$ that it will not recognize a designation made under Article 5 by a person who, at the time of his death, was not or was no longer either a national of, or habitually resident in, the State whose law he had designated, but at that time was a national of and habitually resident in the reserving State....

Although the reasons supporting this reservation are similar to those supporting Reservation $1 d$, Reservation $1 c$ would displace the chosen law in many cases when family members would not be prejudiced by the decedent's choice, even when no survivor had a connection to the place of the decedent's ultimate residence and nationality. This author does not endorse Reservation $1 c$ because (1) she considers it overly broad in comparison with Reservation $1 d$, (2) what was a reasonable choice of law at the time the decedent wrote his or her will should be sustained unless there are strong policy reasons to the contrary, and (3) reservations to treaties should be avoided to the extent consistent with sound policy. Accordingly, Reservation $1 c$ is not discussed further in these pages. Reservation $1 d$, in contrast, is conservatively drawn and essential to preserving important family protection policies, as discussed in the text.

33. Article 3 of the Succession Convention reads:

1 Succession is governed by the law of the State in which the deceased at the time of his death was habitually resident, if he was then a national of that State.

2 Succession is also governed by the law of the State in which the deceased at the time of his death was habitually resident if he had been resident there for a period of no less than five years immediately preceding his death. However, in exceptional circumstances, if at the time of his death he was manifestly more closely connected with the State of which he was then a national, the law of that State applies.

3 In other cases succession is governed by the law of the State of which at the time of his death the deceased was a national, unless at that time the deceased was more closely connected with another State, in which case the law of the latter State applies.

34. Succession Convention art. 24, para. $1 d$. 
In effect, this language permits a reserving state to impose mandatory provisions against the testator's expressed wish only if, on the date of death, both the testator and the surviving spouse or child were closely connected with that country. Although more protective of survivors than the Convention's otherwise applicable rule, Reservation $1 d$ is nonetheless potentially more onerous for survivors than the traditional American rule. That rule, which increasingly applies the mandatory provisions of the law of the decedent's domicile at death, does not ask whether the protected parties are local residents or citizens. ${ }^{35}$

\section{$\mathrm{V}$}

\section{NON-YIELDING RULES IN RELATED CONTEXTS}

\section{A. The Hague Trusts Convention}

Reservation $1 d$ is also less broad than the protection authorized by the Hague Trusts Convention. ${ }^{36}$ Article 15 of that Convention excludes from the settlor's choice of law any mandatory provisions that would be applied by the forum's usual choice-of-law rule (that is, those that would apply if there were no express choice of law in the trust instrument). In other words, in contrast to the Succession Convention, the Trusts Convention never permits a settlor to avoid the otherwise applicable mandatory rules of family protection. These are defined as rules that "cannot be derogated from by voluntary act, relating in particular to ... the protection of minors and incapable parties ... the personal and proprietary effects of marriage ... and succession rights, testate and intestate, especially the indefeasible shares of spouses and relatives . . ."

\section{SCOLES \& HAY, supra note $6, \S 20.15$, at 821,824 .}

The law of the decedent's domicile at death will generally determine the right of a surviving spouse to a statutory forced share out of the personal assets of the decedent ....

In the conflict of laws setting, these policies strongly suggest the predominant relationship to and concern of the state of the decedent's domicile, the usual center of family life. This choice of law reference to the domicile is explicit in the Uniform Probate Code provision for the surviving spouse's elective share (citing Unif. Prob. Code $\$ 2-201$ ).

Of course, as discussed above, it is also possible that the place of domicile at death will be less generous with survivors than a place of earlier domicile and that the decedent may have initiated a move in order to avoid the more onerous laws. From a family law perspective, it is unfortunate that none of the U.S. or Convention models (with or without Reservation 1d) employs a rule of alternative reference to apply the rule most solicitous of surviving spouses and children.

36. See Hague Convention on the Law Applicable to Trusts and on Their Recognition, July 1, 1985, art. 15, 23 I.L.M. 1389, 1390 (1984) [hereinafter Trusts Convention]. This disparity was pointed out during the debates by Delegate José-Luis Siqueiros of Mexico, who remarked that proposed language similar to that included in Reservation 1d "had been adopted in the Conventions on Trusts and Sales and in the Rome Convention on the Law Applicable to Contractual Obligations [and] it was difficult to see why there was such hesitation now." See Working Document No. 79, 2 SUCCESSION PROCEEDINGS, supra note 1, at 325, 470; Succession Convention, supra note 1, art. 24, para. 1d; see also infra note 37.

37. Trusts Convention, supra note 36, art. 15. Professor Scoles states that the Trusts Convention "defers to the choice of law governing forced shares of family members," while the Succession Convention "provides that choice of law governing forced shares to which the Trust Convention defers." Scoles Memorandum, supra note 2, at 4. This is but another way of saying that the Succession 


\section{B. Contract Law}

The balance the Trusts Convention strikes is similar to one undertaken as to contract law by the Restatement (Second) of Conflict of Laws section 187(2). That paragraph addresses the degree to which party autonomy in contract law (not probate or trust law) should be permitted to vary mandatory (or nonyielding) provisions of otherwise controlling law:

(2) The law of the state chosen by the parties to govern their contractual rights and duties will be applied, even if the particular issue is one which the parties could not have resolved by an explicit provision in their agreement directed to that issue, unless either

(a) the chosen state has no substantial relationship to the parties or the transaction and there is no other reasonable basis for the parties' choice, or

(b) application of the law of the chosen state would be contrary to a fundamental policy of a state which has a materially greater interest than the chosen state in the determination of the particular issue and which ... would be the state of the applicable law in the absence of an effective choice of law by the parties.

The tensions under Restatement section 187(2) and Reservation $1 d$ of the Succession Convention's Article 24 are the same: Where choice-of-law problems may arise, parties should be permitted to avoid them by making a reasonable choice of law. Yet it is important to restrict choices that are intended to, or in fact do, evade important mandatory rules of the place with the closest connection to the case. Those rules, after all, are designed precisely to restrict a party's ability to make whatever plans he or she might wish.

Reservation $1 d$ would permit a country that is deeply concerned with fairness between family members at the time of death and the probable task of caring for any survivors left impoverished by the decedent's choice of law to insist that its mandatory survivorship rules be honored whenever they are significantly more generous.

The tests imposed by the reservation are reminiscent of the Restatement's test. Section 187 permits party autonomy in contract law where the chosen law has some relationship to the situation (as would always be the case under Article 5 of the Convention) unless three factors combine to make that undesirable:

1: the chosen law contravenes a fundamental policy of

2: a state with a materially greater interest than the chosen state in the determination of the particular issue, and

3: that state is the state whose law would apply absent an effective choice of law.

Treating these considerations in reverse order, Reservation $1 d$ states expressly that only the law that would apply under the Convention absent an

Convention seeks to alter the rules as to succession law that were accepted by the Trusts Convention. The question addressed in this Article is the degree to which the Succession Convention's proposed changes are undesirable and should be ameliorated through Reservation $1 d$. 
effective choice may supersede the chosen law. This is consistent with factor 3 under the Restatement test.

That this state has a materially greater interest than the chosen state seems to follow, since it is both the site of the testator's closest connections (as identified by Article 3) at the time of death and also the place of habitual residence or nationality of the surviving spouse or child who would be left "totally or very substantially deprive(d) ... of an inheritance or family provision to which [that person] would have been entitled under the mandatory rules of [that state]." Although the testator's assets may be located in several states and other survivors may be located elsewhere, the state identified by Reservation $1 d$ would clearly be the one most interested in the relationship between the testator and these surviving parties (that is, in fairness questions) and most intimately concerned with possible public support needs of its surviving nationals and residents. This is consistent with factor 2 of the Restatement test.

The final requirement under section 187 (factor 1 above) is that the exclusion of the survivor's rights would be contrary to a fundamental policy of the survivor's home state. Whether the total or near-total loss of a forced share or family provision meets this contract law test may be subject to some debate. On one hand, Reservation $1 d$ requires neither that impoverishment be shown in some absolute sense nor that the deprivation violate ordre public (which the Conventions treats elsewhere at Article 18). ${ }^{38}$ On the other hand, it is reasonable to conclude that a state's concern with what it considers to be

38. This distinction is important, since disagreement exists as to whether mandatory survivorship provisions do or can rise to the level of public policy concerns that permit an ordre public exception to the convention's rule. See the correspondence between Professors Bruch and Scoles:

Although I do think family protection on the facts covered by the reservation probably reaches the level of ordre public, the reservation permits countries to decide that they wish their mandatory provisions to apply under the specified circumstance without establishing that ordre public has been contravened. This effort at clarity was probably meant to curtail arguments such as those implied by your letter [of March 11,1991] to the effect that survivor protection laws cannot rise to the level of ordre public.

In the Trusts Convention, as under Reservation $1 d$ of the Succession Convention, there is no requirement that mandatory survivorship rule[s] be independently justified on the basis of ordre public.

Bruch-Scoles Letter (Sept. 22, 1991), supra note 2, at 2. This explanation for the provision was given in the debates. See 2 SuCCESSION PROCEEDINGS, supra note 1, at 468-70 (especially the remarks of Delegates José-Luis Siqueiros of Mexico and Gonzalo Parra-Aranguren of Venezuela).

I simply disagree that the differences, interstate or internationally, between interested states in the manner by which spouses or other family members are protected reach the level of ordre public. The variations are so frequent and are so regularly treated as ordinary variations of result by reason of choice of law that I would not expect a modern American court to disregard the treaty [on grounds of ordre public].

Scoles-Bruch Letter (Oct. 29, 1991), supra note 2, at 1. Cf. Irish Law Reform Commission Report 361991, at text accompanying note 55 [hereinafter Irish Comm'n Report]:

Even if [Reservation $1 d$ ] were not available, we are of the view that Article 18 [authorizing ordre public] would probably reach [a testator's designation that would have the effect of totally or very substantially depriving one spouse or child of the deceased of an inheritance or family provision to which he or she would have been entitled], but it is beneficial that the policy can be spelt out plainly through making this reservation. 
minimally fair treatment for surviving spouses and children is fundamental, particularly when a decedent and a survivor are both closely aligned with that place. By authorizing Reservation $1 d$ for this situation, the Convention suggests as much.

\section{VI}

\section{POLICY IMPLICATIONS}

Reservation $1 d$ raises questions of family and social policy. The Succession Convention was drafted to enable those with multinational contacts to make estate plans upon which they can rely. That goal does not require, however, that testators be given a device to avoid rules designed for the protection of their survivors. Reservation $1 d$ was provided to restrict the testator's ability to treat close family members in a manner sharply contrary to the law of the state with which he or she and the spouse or children were closely connected at the date of the testator's death.

Because it tests the validity of decedents' dispositions by the situation at the time of death rather than at the time of signing, however, it imposes a degree of uncertainty: results will depend on where the testator and surviving family members live, not on the date of signing, but when the testator dies. ${ }^{39}$

This test may affect not only those who move to this country, but also those who move abroad. In practical terms, then, if the Convention is ratified by the United States, wills drawn here will be subject to Reservation $1 d$ abroad if, at the time of the testator's death, the testator and survivors are closely connected with a country that has taken the reservation. ${ }^{40}$ Accordingly, whether or not this country enters the reservation, if the United States ratifies the Convention, U.S. attorneys will have to inform a testator that if the circumstances described by Reservation $1 d$ come about in any country having taken the reservation, the decedent's estate will be tested there by its mandatory survivorship rules. This will be of concern, of course, only if the testator attempts to restrict the inheritance of someone protected by those mandatory rules without obtaining a valid waiver from the protected party. ${ }^{41}$

39. The testator's final habitual residence and nationality, rather than those existing at the time of signing, control other cases as well. That is, a testator who chooses the law of a place with which he or she has no tie of habitual residence or nationality must have one of those connections in place at the time of death if the choice is to be honored. Here the Convention permits a testator's unilateral actions to change the laws controlling his or her estate.

40. Australia, for example, which proposed this reservation, will surely take it if that country ratifies the Convention. Because its states' family provision legislation is potentially more generous to survivors than are U.S. mandatory survivorship provisions, this may affect wills in which the law of an American state has been designated by the testator. The reservation is under serious consideration in other countries as well. Conversation with Professor David Hayton, King's College (London), in London (Oct. 1991) (concerning England); Irish Comm'n Report, supra note 38, at text accompanying n.55 (recommending the Convention's ratification by that country, subject to the entry of Reservation $1 d$ ); supra note 31.

41. See Example 1 in the Appendix. 
The converse situation (a will drawn abroad that involves parties closely affiliated with the United States at the time of death), may not produce a deviation from the testator's choice even if the United States has taken Reservation $1 d$. This follows to the extent that our protections for survivors are not significantly greater than those imposed by the foreign law chosen by the testator. Within the United States, the balance between domestic and foreign law would vary from state to state, of course, depending on the mandatory features of each state's law. ${ }^{42}$

How important is the reservation, then, in practical terms? Virtually all common law states grant surviving spouses a forced share, generally consisting of one third of the estate's assets. It is difficult to estimate how often this would provide a significantly more generous result than a foreign law, for example, under a discretionary award of family provision. And only a few states now have quasi-community property laws that might more frequently displace a testator's choice under the Convention. Nevertheless, the citizens in these quasicommunity property jurisdictions comprise a significant percentage of this country's population. ${ }^{43}$ Furthermore, the number of such states is growing, and this trend can be expected to continue. Of the four states with quasi-community property laws that would be affected by the Convention, two of them only recently added this feature to their law. ${ }^{44}$ In one case, this step was influenced by the Uniform Marital Property Act, currently under consideration in several states, which embraces the concept of quasi-community property. ${ }^{45}$ Scholarly commentary also supports this expansion ${ }^{46}$ and endorses other steps that would enhance mandatory survivor protection in non-community property states. ${ }^{47}$

To the extent that these law reform efforts bear fruit, they will increase the practical importance of the reservation, if taken. But unless Reservation $1 d$ is entered at the time of ratification, these increased protections will be irrelevant to the fact patterns discussed in this article. For, as a matter of treaty law, reservations may not be entered at a later time. ${ }^{48}$ To preserve the options for

42. See Example 2 in the Appendix.

43. California alone accounts for almost $12 \%$ of the United States' population. When the other states that recognize quasi-community property at death (Idaho, Louisiana, and Wisconsin) are considered as well, the total rises to approximately $15.45 \%$. See THE WORLD ALMANAC AND BOOK OF FACTS 74-75 (Mark S. Hoffman, ed. 1992); supra note 11.

44. SCOLES \& HAY, supra note $6, \S 14.14$, at 488 (listing California, Idaho, Louisiana, and Wisconsin, the final two of which have reformed their laws within the past decade).

45. Wisconsin is the first state to enact the Uniform Marital Property Act, including its concept of quasi-community property at death. See WIS. STAT. ANN. $\$ 861.02$ (West 1991) (using the term deferred marital property); UNIF. MARITAL PROP. ACT $\S 18$ (1983), 9A U.L.A. 97, 139 (1987). Cf. WIS. STAT. ANN. $\& 766.75$ (and annotation of Legislative Council Notes-1985 Act 37, $\S 141-143$ ) and $\S 767.255$ (West 1981 \& Supp. 1991) (both concerning divorce).

46. SCOLES \& HAY, supra note $6,814.14$, at $488-89$.

47. See J. Thomas Oldham, Should the Surviving Spouse's Forced Share be Retained?, 38 CASE W. RES. L. REV. 223, 245-53 (1987) (common law forced spousal share should be reformed to resemble more closely community property system and to provide a form of support for the survivor); Haskell, supra note 5 , at $518-25$.

48. Succession Convention, supra note 1, art. 24; Vienna Convention on the Law of Treaties of May 23, 1969, art. 19, 1155 U.N.T.S. 331, 336-37. 
state legislatures to enhance effective mandatory survivorship provisions, then, the United States must act at the time of ratification. ${ }^{49}$

It is also important to note that the view presented here that generally this country's state laws are not as solicitous of survivors as are those of other countries (and, accordingly, that the reservation would be invoked relatively infrequently as matters now stand) is based only on comparisons with the laws of Continental and common law countries. ${ }^{50} \mathrm{~A}$ far broader range of foreign

49. Professor Scoles has suggested that Reservation $1 d$ is unnecessary because "the forum can provide, as nearly all the states of the U.S. provide, substantial benefits through the interim exemptions and allowances customarily made as an administrative matter, not within the Convention." Scoles Memorandum, supra note 2, at 2 . His statement refers to family allowances (which provide temporary support during administration of the estate), homestead laws, and claims against estates for public support, which he considers to be "elements of administration of estates and not touched by the Convention." Scoles-Bruch Letter (Mar. 11,1991), supra note 2, at 2. Contrast note 50 infra (questioning the adequacy of the benefits granted by these laws) and SCOLES \& HAY, supra note $6,820.15$, at 823 (describing English law as "more generous"). Professor Scoles' statement that administration of estates as understood in the common law context has been excluded finds support in the Reporter's comments. See Donovan W.M. Waters, Explanatory Report (May 1989), in 2 SUCCESSION ProCEEDINGS, supra note 1, cl. 24, at 535; RESTATEMENT (THIRD) OF FOREIGN RELATIONS LAW, Introductory Note to part III, at 145 (1986).

His assumption that these protections could be expanded and extended after ratification to cases in which a foreign law controls the estate under the Convention, however, appears doubtful. The drafters defined the Convention's coverage in article 7 and specified various exclusions in article 1 , without referring to matters of "administration" as such. The language in article 7 seems sufficiently precise to prevent avoidance of the Convention through labelling (or characterizing) significant property transfers in a way that places them beyond the Convention's reach. Article 7, paragraph 2 of the Convention states that anything determining the disposable part of the estate and the shares or other succession rights "including provision by a court or other authority out of the estate of the deceased in favour of persons close to the deceased" are controlled by the applicable law. In this context, it seems legitimate to view family allowances as the United States' modest, highly restricted version of the family provision statutes of other common law countries. If so, they, like family provision, fall squarely within the Convention. Although a state's claim as a creditor for past support rendered the decedent's children during his or her lifetime would seem to fall outside the Convention, a claim for the future care of survivors who would otherwise be left public charges (another feature of some U.S. state laws) again seems encompassed by the Convention's treatment of family provision. See, e.g., CaL. Civ. Code $\$ 205$ (West 1982) (support for child otherwise requiring public support).

Even if current family allowance statutes lie outside the Convention (under Professor Scoles' reasoning that they are properly characterized for Convention purposes as matters of administration), they are quite unlikely to be reformed in any way to provide significant protections for the survivors who are the protected parties under Reservation $1 d$. A state that sought to do more than simply recompense the public fisc for welfare costs associated with the decedent's surviving minor children might enact legislation providing a specific forced share for them or, alternatively, might authorize the probate court to award family provision on their behalf (for example, through a property award or long-term support order). See, e.g., WIS. STAT. ANN. \& 861.35 (authorizing long-term support for spouse and minor children), $\$ 861.41$ (authorizing exception for spouse's support) (West 1991); Haskell, supra note 5, at 518-26 (recommending forced shares). These reforms, of course, could not be characterized as matters of the administration of estates for purposes of the Convention.

For the Reporter's discussion of administration of estates under civil law and common law systems, including the impact of the Convention on these varying conceptual schemes, see Waters, supra this note. Cf. Schoenblum, supra note 1 , at 89-90 n.29, 96-97 n.56.

50. Professor Scoles suggests, to the contrary, that U.S. probate law will almost always be nearly as generous as a foreign law designated by the decedent. He therefore concludes that a successful challenge under Reservation $1 d$ would be rare. He also argues that the reservation would invite litigation. Scoles Memorandum, supra note 2, at 2-3. His discussion of the relative generosity of U.S. state law and foreign law, however, focuses on matters of estate administration under U.S. law such as family allowances and homestead exemptions. These are related only indirectly to the reservation, which 
laws may be relevant under the Convention. And, whatever the abstract likelihood of one result or another, at any time that a testator and survivors were closely connected to a.U.S. state whose law was vastly more protective than that chosen by the testator, we would probably be seriously distressed at how little was guaranteed unless the law of that state could be applied. Precisely these concerns were articulated during the drafting by the delegate from Australia:

\begin{abstract}
He gave the example of the migrant, long settled in a new country, who might defeat the legitimate expectations of immediate family members by choosing the law of his nationality where that law made little or no mandatory provisions for them.... Although within the membership of the Hague Conference there was a general assurance that States could be relied upon to have made provision for surviving dependants, this would not necessarily be the case for all of the other 100 or more States whose nationals had settled in Australia. This was an extremely serious problem for an immigrant nation such as his. ${ }^{51}$
\end{abstract}

Of course, as Professor Scoles has pointed out, only a small percentage of all testators seeks to disinherit or disfavor close family members. ${ }^{52}$ It is quite possible, however, that this percentage is higher in cases involving international wills, since these testators as a group may be more affluent. If the wealthy are financially able to undertake more sophisticated estate planning efforts and have the motivation to do so, they may well be over-represented among those whose testaments and relocations seek specific goals, including efforts to minimize the claims of family members on their estates. ${ }^{53}$ Whatever its incidence, in this

in no way displaces administrative matters, but tests instead the relative generosity of inheritances or family provision. While the assets in the estate (and hence the absolute dollar value of a forced share) will be reduced by whatever amounts are excluded as a matter of administration, these reductions occur in any event and therefore affect the estate's size no matter which mandatory law applies. If, despite this smaller corpus, a sharp disparity remains in the amount that would be recovered if the forum's mandatory provisions were to control, the effect of the testator's choice is abundantly clear. Professor Scoles cites the potential worth of those features of probate administration in California as examples of their sufficiency in the event California were not permitted to apply its significantly more generous quasicommunity property laws under the Convention. Id. at 3:

For example the protection against indigency, even prior to creditors, found in homestead exemption and family allowances, not covered by the Convention include in California: homestead, $\$ 30,000-\$ 75,000$ (Prob. Code 6520) ([U.P.C. $\$ 2-402$ (West Supp. 1992)] is $\$ 15,000$ ), plus household effects and equipment $\$ 2,500: \$ 4,000$ insurance and $75 \%$ of last month's income ([U.P.C. $\$ 2-403$ (West Supp. 1992)] is $\$ 10,000$ ). In addition . . . a family allowance [of a reasonable amount during administration] is usually quite generous [in California] and awards in excess of $\$ 20,000$ are not unusual (Prob. Code 6540).

These figures do not assuage this author's concern. To the contrary, they seem seriously inadequate, given the price of housing and the overall cost of living in California. It is also important to remember that these benefits are provided in the context of a marital property regime in which it is expected that they will provide but a supplement to the surviving spouse's right to one-half of all community assets, to one half of the decedent's quasi-community property assets, and to all quasicommunity property assets the survivor acquired.

51. 2 SUCCESSION PROCEEDINGS, supra note 1, at 492 (remarks of Mr. Edwards of Australia).

52. Scoles Memorandum, supra note 2, at 5. "People change [habitual residence] or citizenship for reasons other than preclusion of spouses." Scoles-Bruch Letter (Oct. 29, 1991), supra note 2.

53. See, e.g., Dorrence's Estate, 170 A. 601 (N.J. 1934); Dorrence's Estate, 163 A. 303 (Pa. 1932); Newcomb's Estate, 84 N.E. 950 (N.Y. 1908) (cases in which wealthy testators sought domiciles in order to choose the law applicable to their estates); Phyllis K. Fairbanks, et al., Multi-State Death Tax Problems 
author's view, an egregious act, however infrequent, is worthy of corrective legal action when that can be accomplished without difficulty. Reservation $1 d$ provides a remedy in precisely such cases, without imposing any countervailing harms. As a simple, available protection against a foreseeable danger, the author counsels its adoption..$^{54}$

A possible disincentive to entering the reservation, however, is the prospect that a testator's hoped-for unified disposition may be thwarted, since in practice the reservation may only control the disposition of assets located in the territory of the state imposing its own law under the reservation. It is also possible that some survivors may live in a state qualifying under Reservation $1 d$, while others live elsewhere, so that differing protective rules might apply to them. ${ }^{55}$ In the end, the question for these cases is whether some protection, albeit incomplete, is preferable to no protection at all.

The ultimate policy question posed by the reservation is whether it identifies circumstances in which a testator should be denied the plan he devised. ${ }^{56}$ If this country enters Reservation $1 d$, those who will most frequently be protected by American laws will be older women and, derivatively, their children. ${ }^{57}$ Because

of Estates and Trusts, 21 ReAl Prop. Prob. \& Tr. J. 527, 529-32 (1986) (describing Howard Hughes' efforts). The personal representatives of Howard Hughes' estate argued that he was domiciled in Nevada (a state without death taxes), not California (with a marginal death tax of $24 \%$ ) or Texas (with a 16\% rate). See California v. Texas, 437 U.S. 601, 603 n.2 (1978); California v. Texas et al., 457 U.S. 164, 165-66 (1982). Accord Schoenblum, supra note 1, at 97 n.56 ("Experience with forced heirship and taxation strongly supports the conclusion that persons with 'international' estates will go to great lengths to shift the [situs] of assets in order to obtain the application of favorable rules," citing several essays, including one on planning to avoid forced heirship in INTERNATIONAL ESTATE PLANNING: PRINCIPLES AND STRATEgIES (Donald D. Kozusko \& Jeffrey A. Schoenblum eds. 1991)).

54. As legal questions go, the inquiry required by Reservation $1 d$ is relatively straightforward and objective, and places no particular burdens on the judicial system. Even-or especially-if, as Professor Scoles suggests, it would be difficult for a claimant to establish the elements necessary for recovery under the reservation, the logical conclusion is that few frivolous claims will be brought, and fewer yet will be successful, rather than the contrary. Compare Scoles Memorandum, supra note 2, at 2 (stating Professor Scoles' view):

[T] he proposed reservation practically requires and encourages litigation because of its exceptionally ambiguous and difficult to apply substantive requirement of proof that the designated law "would totally or very substantially deprive" the claimant "of an inheritance or family provision to which the claimant would have been entitled" under the mandatory laws of the forum. The probability of this being able to be demonstrated is small [because of the monies available through probate administration].

For this author's conclusion that amounts available under probate administration may well be inadequate, see supra note 50.

55. Because of what may be a drafting oversight, it is possible that other member states will be required to honor the testator's choice of law even when it has been denied effect under Reservation $1 d$ at the place of the testator's final residence and nationality. Countries that do not belong to the Convention, of course, would remain free to apply the law of the testator's final residence and nationality under choice-of-law rules favoring the unity of succession.

56. A related question is whether mandatory rules should be given less effect under the Succession Convention than under the Trusts Convention. This discrepancy could be alleviated somewhat by entering Reservation $1 d$.

57. Because men's life expectancies are less than women's of the same age, and because this difference is exacerbated by the frequency with which men marry women younger than themselves, women outlive their husbands far more frequently than the converse. See U.S. BUREAU OF THE CENSUS, STATISTICAL ABSTRACT OF THE UNITED STATES: 1991, at 73, table 106 (111th ed. 1991) [hereinafter 
elderly women are among the poorest in our society, it may be thought desirable to at least maintain those protections currently available to them. ${ }^{58}$

\section{VII \\ CONCLUSION}

Reservation $1 d$ in no way impinges upon the legitimate aims of the Succession Convention. Rather, it fine-tunes the Convention in a way that advances its auspicious aspects while curtailing untoward effects that its general provisions threaten for a narrow but important range of cases. It should be entered by the United States if the Succession Convention is ratified.

Statistical Abstract]; Staff of Senate Special Committee on Aging, 101st Cong., 2d Sess., INFORMATION PAPER ON AgING AMERICA: TRENDS AND PROJECTIONS (Annotated) 13-16 (Comm. Print 1990) (Serial No. 101-J). Although children generally outlive their parents, they would rarely benefit directly by Reservation $1 d$, as mandatory provisions for their protection are relatively modest in the United States. As a practical matter, however, they may become beneficiaries of their mother's assets, either during her lifetime or at her death.

58. See StatistiCAL ABSTRACT, supra note 57, at 458, tbl. 737. The author assumes that, as a group, widows who have been well provided for by wills are better off than those who have not and that elderly widows are in general better off than elderly divorcees. The Statistical Abstract does not distinguish between these groups, nor does it provide any direct measure of property holdings (as opposed to income). See generally Oldham, supra note 47, at 248-51 and sources cited (discussing economic impact of widowhood). 


\section{APPENDIX}

Example 1. U.S. attorneys will be required to give advice about Reservation $1 d$, whether or not the United States enters the reservation:

A divorced New Yorker wishes to disinherit his children, who still live in the country of his origin. Although New York local law permits such disinheritance, the country of the children's residence does not. Even if that country has entered the reservation, their father's attorney could prepare the will he requests, indicating a choice of New York law. Counsel would then, however, have to inform the testator that his children will be able to take despite the will (at least out of his assets in their country) if the conditions of $1 d$ are met at the time of his death. Indeed, if it is possible that the testator and his children will share residence and domicile in some other country that gives the children rights in his estate and that country is either not a party to the Convention or is a member state that has taken the reservation, he will need to be told of the circumstances under which his attempted disposition may not be honored.

Example 2. If the United States does not take the reservation, testators of whatever nationality (including expatriate U.S. citizens) will be permitted to avoid the application of U.S. mandatory laws that are intended to protect their survivors:

A United States national who has worked in several countries abroad for many years as an executive, is now on an 18-month contract in England. He plans to retire in California, and wants an estate plan that will avoid operation of California's quasicommunity property laws-laws that would give his American wife fifty percent of the assets acquired by his labor during their marriage, including those acquired while they were domiciled abroad. These assets constitute the vast bulk of his estate. Either he does not wish to ask his wife to waive her rights (perhaps because he does not wish her to know of his estate plan, perhaps because he does not want her to learn of her rights), or he has asked her to waive her rights and she has refused.

In either event, he prepares his will, designating English law, as authorized by Article 5, paragraph 1, and leaving his wife one fifth of the assets that would constitute quasi-community property in California, but nothing else. He and his wife do in fact retire to California and his death occurs there some months, years, or decades later.

If the United States has not taken Reservation $1 d$, his estate plan will stand unless his widow can obtain family provision under English law (Article 7, paragraph 1a)." If the United States has

* Under current English law, she would have no right to apply for family provision, as the statutes apply only to the estates of decedents who died domiciled in England, and her husband was domiciled in California at the time of his death. See Inheritance (Provision for 
taken the reservation, his widow can claim the protections of California law.

Family and Dependants) Act 1975, \& 1. Professor David Hayton of King's College (London), a member of the British delegation to the Conference when the Convention was drafted, expects this provision of English law to be amended to permit family provision for any case governed by English law, should England ratify the Convention. Conversation with Professor David Hayton, in London (Oct. 1991). Family provision under the statute is purely a matter of a court's discretion. It must be requested and, if granted, may consist of anything from a small portion of the estate to its entirety. Conversation with David C. Bradley, Lecturer in Law, London School of Economics and Political Science, in London (Oct. 1991). See Inheritance (Provision for Family and Dependants) Act 1975, $\$ \$ 1-4$. 